\title{
Procuring, Crafting, and Sensing: Affect and Material Practices of Russian Women in Japan
}

\author{
K. V. Golovina
}

For citation: Golovina K. V. Procuring, Crafting, and Sensing: Affect and Material Practices of Russian Women in Japan. Vestnik of Saint Petersburg University. History, 2018, vol. 63, issue 2, pp. 488-505. https://doi.org/10.21638/11701/spbu02.2018.211

This paper draws its data from fieldwork on female Russian migrants in Japan, paying close attention to their material practices and, notably, their craftwork. The discussion focuses on the objects and clothes observed in localities where these material practices are enacted, namely, migrants' homes and places where migrant festive events take place. Second-hand shops are discussed in detail as a popular shopping destination among Russian migrants. This paper also looks at online groups for Russian-speaking migrants in Japan that serve as sites for the display and exchange of their material possessions. In these offline and online spaces, migrants search for ways to affectively reenact the materiality and accompanying sensations of their pre-migratory past, while simultaneously interiorizing the material expressions of the host culture. By investigating the connection between migration and materiality through the evocative ethnography approach, this study attempts to explore how the affective turn in social inquiry helps us better capture the multilayeredness of migrant experiences. The processes of procuring, making, and sensing that the migrants are engaged in and the resulting objects function as locales charged with affective forces that enable actors to subdue the displacement they have experienced as a result of migration and try out new meanings and modes of being. Keywords: affect, material practices, migration, Russian women, Japan.

Ksenia V. Golovina - PhD, Project Assistant Professor, Center for Global Communication Strategies, College of Arts and Sciences, The University of Tokyo, Komaba 3-8-1, Meguro Ward, Tokyo, 153-8902, Japan; kgolovina@cgcs.c.u-tokyo.ac.jp

Ксения Валентиновна Головина - PhD, асс.-проф., Центр стратегий глобальных коммуникаций, Факультет искусств и наук, Токийский университет, Япония, 153-8902, Токио, Район Мегуро, Комаба 3-8-1; kgolovina@cgcs.c.u-tokyo.ac.jp

The research was carried out with partial financial support: Japan Society of Lifology: Lifology Project 2015 (Nihon seikatsu gakkai: Seikatsugaku Purojekuto 2015/日本生活学会生活学プロジェクト2015).

(C) Санкт-Петербургский государственный университет, 2018 


\section{Материальные практики россиянок в Японии с точки зрения аффективной перспективы}

\section{К. В. Головина}

Для цитирования: Golovina K. V. Procuring, Crafting, and Sensing: Affect and Material Practices of Russian Women in Japan // Вестник Санкт-Петербургского университета. История. 2018. Т. 63. Вып. 2. С. 488-505. https://doi.org/10.21638/11701/spbu02.2018.211

В работе используются данные полевых работ, объектом которых являются женщины из России, проживающие в Японии, в частности, их материальные практики. В фокусе исследования - предметы и одежда, зафиксированные в местах, где разворачиваются материальные практики информанток: их домах и местах проведения мигрантских праздников. В статье рассматриваются магазины товаров, бывших в употреблении, как популярное место покупок среди русских в Японии. Также уделяется внимание онлайн-группам, где происходит общение русскоязычных мигрантов в этой стране. Данные группы служат в качестве пространства, где участники выставляют напоказ свое имущество и обмениваются им. В исследуемых оффлайн- и онлайн-пространствах мигранты ищут способы аффективно воспроизвести материальность премигрантского прошлого и сопровождающие его сенсорные ощущения, одновременно присваивая материальные выражения принимающей страны. Через анализ связи между миграцией и материальностью посредством методологии эвокативной этнографии в исследовании предпринимается попытка определить, каким образом обращение к проблематике аффекта в социальных науках дает возможность переосмыслить многогранность мигрантского опыта. Процессы, связанные с приобретением, созданием и сенсорным восприятием материальных предметов, наблюдаемые среди российских мигрантовженщин в Японии, а также сами предметы функционируют как локусы, наделенные аффективными силами, помогающими мигрантам справиться с ощущениями потери почвы вследствие перемещения и испробовать новые смыслы и формы бытия.

Ключевые слова: аффект, материальные практики, миграция, российские женщины, Япония.

\section{Introduction}

This paper brings together discussions of the material practices of Russian migrants in Japan that unfold in both physical and virtual spaces. The three cases to be examined took place in a second-hand shop with a further relocation to a migrant's home, at a celebration involving a theatrical performance, and in an online group where Russian-speaking migrants in Japan communicate. The uniting feature of these three discussions is their focus on material practices that involve elements of a do-it-yourself (DIY) approach, whether it refers to an item's actual handmadeness or to the co-made nature of the endeavor surrounding its procurement or creation. Another feature that links the findings presented in this paper is their affective nature; the paper explores the potential of the migrants' material practices and the objects involved as mediums for an "affective force". Over the last several decades the affect phenomenon has preoccupied scholars attempting to establish "the new epistemology" coined as an "affective turn" in the scholarly disciplines ${ }^{1}$. Further,

${ }^{1}$ Athanasiou A., Hantzaroula P., Yannakopoulos K. Towards a New Epistemology: The "Affective Turn" // Historein. 2008. Vol. 8. P. 5. 
the present study attempts to incorporate an "evocative" ethnography approach. Evocative ethnography is "an ethnography that meets [the] challenge to make room for, and hold onto, feelings and affect in its description and explanation"2. Giving attention to sensory details of the informants' experience is believed to help achieve this methodological purpose. This paper aims to explore these theoretical and methodological frameworks.

\section{Notes on Affect}

White has defined affect as "a dimension of human feeling generative of discourse but often circulating in and between bodies outside of conscious recognition and articulation" ${ }^{3}$. Affect has to do with the "bodily intensity and dynamism that energize the forces of sociality" ${ }^{4}$. In contrast to something that can be experienced as a story, affect is rather a "momentum or force [...] of the welling up of energies" that often leads to unpredictable outcomes 5 . Skoggard and Waterston have argued that "affect can be understood as a prompt to action" that affects both the actor and the recipient(s) of the act. Born out of "interrelationship", it is thus intersubjective in nature ${ }^{7}$.

Critiques of affect theory include perspectives that challenge its existence outside socio-cultural formations. Martin, for instance, has offered an account of "intentionality", speculating that affects may be a social product, "an effect of social processes that have worked to make them materialize" 8 . That there are many studies that collectively attempt to capture the "hidden force emanating from fruitful darkness", on the one hand, and to question its very essence as something paired with human instincts, on the other, suggests that the question of the nature of affect remains open and requires further investigation.

The context this paper engages with is that of migrant displacement, of life away from one's country of birth and upbringing. This displacement gives forth affective spaces that accumulate in ways that are often unarticulated but which share notions of selfhood, identity quests, and communal longings. Affect can be felt in the sharedness of such notions - as when members of a certain community surround themselves with objects and, through them, with affective flows that connect their holders to lost or displaced social orders and relationships. Latour's theoretical contemplations on "interobjectivity" apply here: if objects are the often unaccounted-for but real mechanisms that bridge the gulf between individuals and social structure by holding this structure together ${ }^{10}$, it is only natural that actors turn, at times unconsciously, to the world of objects to restore, even if partially, the social order they have departed from. In this case, the actors are migrants. The defining contexts of coping, re-making oneself, and establishing generational conti-

${ }^{2}$ Skoggard I., Waterston A. Introduction: Toward an Anthropology of Affect and Evocative Ethnography // Anthropology of Consciousness. 2015. Vol.26, N 2. P. 109.

${ }^{3}$ White D. Notes Toward an Affective Anthropology of International Relations // The Hosei Journal of Global and Interdisciplinary Studies. 2017. P. 129.

${ }^{4}$ Athanasiou A., Hantzaroula P., Yannakopoulos K. Towards a New Epistemology... P. 6.

5 White D. Affect: An Introduction // Cultural Anthropology. 2017. Vol. 32, N 2. P. 178.

6 Skoggard I., Waterston A. Introduction: Toward... P. 115.

7 Ibid. P. 111, 115.

${ }^{8}$ Martin E. The Potentiality of Ethnography and the Limits of Affect Theory // Current Anthropology. 2013. Vol.54. P. 157.

9 Ibid. P. 150.

10 Latour B. On Interobjectivity // Mind, Culture, and Activity. 1996. Vol.3, N 4. P.232-235. 
nuity in migrant life in the host society can be seen as the "powerful forces that set the conditions for making some forms of affect possible and others less likely to happen"11. As such, the environments migrants find themselves in, which they are both affected by and affect, are responsible for stimulating certain affective situations and "making and shaping bodies in ways more complex than and ontologically distinct from the poetics on hand to describe it"12. An illustration of migration being so affectively charged that it collectively affects the bodies of its actors is the case of "resignation syndrome". Registered in Sweden among refugee youths facing deportations, the affected turn into bed-bound "Snow Whites", showing no signs of life ${ }^{13}$. This paper discusses affective forces of a lower register that are responsible for less visible transformations and that are particularly mediated through objects. Nonetheless, it aims to explain the findings through an affective perspective, thus contributing to the discussion on affect and further testing the applicability of this approach.

\section{Migrants, Material Practices, and Affective Experiences}

The material practices of migrants have increasingly become a focus of scientific attention, revealing that the ways in which migrants engage with materiality may help better understand the circumstances of their lives at home and in the country of destination. Burrell, for instance, has focused on female Polish migrants who moved from then-socialist Poland to the West before the 1990s. Burrell argued that the material environment of the consumerist lifestyles, which the migrant women found themselves in, served as stark markers of their changing capabilities. In Poland's shortage economy, these women had been "confident arrangers" of scarce goods often traded through underground markets, while in the West they became confined to the role of "uncertain consumers"14. In this case, the consumer goods - some observed through the windows of the shops and others directly interacted with - affected the migrants in a way so as to make them realize their altered status. In other cases, such as the situations of au pairs from Slovakia working in London, these temporary migrants had to carefully navigate the realm of "ambivalence" when attempting to make their rooms in the homes of host families feel home-like. At the same time, they were prompted to continuously assess the extent to which they felt they were allowed to rearrange their rooms under the conditions of co-living ${ }^{15}$. The initial material settings of the rooms these migrant workers are provided with for the length of their stays act, among other factors, upon their occupants. As a result, migrants assume certain ways of material expressions which, in turn, reveal the migrants' perceptions of their roles and statuses. Materiality of a larger scale (e.g., city environments and weather) affected the retiree male migrants from Japan who relocated to Malaysia to experience "rejuvenation" of the body and mind and ultimately escape the "normative life course" discourse of their

11 Skoggard I., Waterston A. Introduction: Toward... P. 113-114.

12 White D. Affect: An Introduction... P. 175.

13 Aviv R. The Trauma of Facing Deportation // The New Yorker. April 3, 2017. URL: http://www. newyorker.com/magazine/2017/04/03/the-trauma-of-facing-deportation (accessed 10.07.2017).

14 Burrell K. Managing, Learning and Sending: The Material Lives and Journeys of Polish Women in Britain // Journal of Material Culture. 2008. Vol. 13, N 1. P. 64.

${ }^{15}$ Búriková Z. The Embarrassment of Co-Presence: AU Pairs and their Rooms // Home Cultures: The Journal of Architecture, Design and Domestic Space. 2006. Vol.3, N 2. P. 100. 
motherland ${ }^{16}$. These three examples reveal the complex relationships migrants have with materiality and the layers of both affective experiences and discursive meanings that these relationships bring to light. Doi, who has looked at physical encounters with the material world as "transformative forces", has remarked that, "Humans cannot perceive abstract ideologies alone and there is a need for tangible things such as trails and papers. What we share are not interpretations of the forms already made, but transformative forces affecting our different selves and relating to emerging socio-cultural forms"17. This paper will incorporate the perspective that values human engagement with materiality and the outcomes of this engagement and use it for further examination of how the material objects that migrants interact with produce affective forces.

\section{Methods}

This paper employs mixed methods. It combines findings from an ethnographic fieldwork launched in 2008, the results of a 55-question incentivized online survey carried out in February 2016 (funded by Japan Society of Lifology), and cyberethnographic data in the form of narratives and visuals that have been gathered primarily between 2015 and 2017. The methodological insights have been drawn from the evocative approach in the ethnographies of Russian summer homes known as dacha by Caldwell and of Russian migrant homes in the UK by Pechurina. The work of these two authors serve as examples of the researcher's sensory engagement with the material world of the informants.

My ethnographic fieldwork could be divided into two phases: 2008-2011 and 20122017. In 2008-2011, I interviewed 50 Russian females in Japan ${ }^{18}$. Many interviews took place in the homes of the respondents, requiring me to travel extensively to various parts of Japan. Apart from Tokyo, interviews were carried out in Nagoya, Osaka, Kyoto, Kobe, Niigata, and Toyama, as well as smaller towns and villages in their vicinities. In order to introduce a sensory element to the fieldwork, where possible, I remained with my respondents for hours or even days, staying overnight at some of their homes and sharing meals with them if invited. I drank hundreds of cups of tea with them, observing how the scenery outside the window was changing from day- to night-time. These immersive experiences made it possible for me not only to record these women's narratives, but also to observe their actions in various circumstances, pay attention to their homes and the objects within them, and take note of the lifestyles these women led and the daily cycles they followed. The migrants' material world per se was not the central topic of investigation in this first phase of my fieldwork. Rather, the data about material objects developed as peripheral, yet crucial findings. The second, still ongoing phase of my fieldwork involves meeting old and new informants to talk about their material practices ${ }^{19}$.

${ }^{16}$ Shakuto S. Ageing with Bad-Boy Charm: An Affective Analysis of Japanese Retirement Migration in Malaysia // Japanese Review of Cultural Anthropology. 2017. Vol. 18, N 1. P. 161.

17 Doi K. Onto Emerging Ground: Anticlimactic Movement on the Camino de Santiago de Compostela // Turizam: međunarodni znanstveno-stručni časopis. 2011. Vol. 59, N 3. P. 282-283.

18 Golovina K. Nihon ni kurasu roshiajin josei no bunkajinruigaku: Ijū, kokusai kekkon, jinseizukuri. Tokyo, 2017.

19 Additionally, in the course of 2015-2017 I was part of two joint projects on Russian-speaking migrants in Japan with co-researcher Varvara Mukhina, during which 55 people were interviewed. While these projects focused on topics different from the purpose of this paper, and the majority of encounters took 
I am also currently involved in cyberethnographic research in several online networks for Russian-speaking migrants in Japan. As a result, I am able to maintain stronger ongoing connections with my informants than I could before 2011, the year when the online communities of Russian-speaking migrants in Japan started appearing in the aftermath of Great East Japan Earthquake. These digital engagements allow me to obtain a time-stretched vision of my informants' daily lives (to the extent that their online presence is reflective of their offline modes of being) and their placemaking ${ }^{20}$ - as related to material practices - activities. The idea to carry out an extensive survey (in February 2016) in an online Russian-speaking community on a social network was born as a result of this cyberethnographic experience. This survey encompassed a wide range of topics related to the migrants' homes and objects; its findings are partially presented in this paper.

While my research, both individual and joint, has recently incorporated migrants from other post-Soviet countries with Russian-speaking populations in addition to those from Russia, this paper focuses on women from Russia, in particular. The majority of the 8306 Russians residing in Japan are women, according to the official statistics by Japan's Ministry of Justice ${ }^{21}$. Women constitute $68.9 \%$ of the whole population of migrant Russians, and women in their 30s and 40s comprise the majority (63.7\%) of the female Russian population in Japan. The three separate online surveys that I carried out from 2015 to 2017, both independently ${ }^{22}$ and as part of joint projects ${ }^{23}$ ), confirmed these statistics and further captured that female Russians in Japan are highly active in online spaces.

\section{Discussion 1: Second-hand Shopping}

This chapter discusses the material objects and clothes found in the homes of Russians in Japan that were initially procured in second-hand shops. Although I started my fieldwork studies of Russians in particular in 2008, I recorded cases of fascination with Japan's second-hand shops and flea markets among foreigners in Japan as early as 2002. There are various forms of similar shopping practices among foreigners in Japan. For instance, "sayonara sales" (meaning "farewell sales") are popular form of exchange initiated and favored by Japan's foreign community members. They can be seen as an extension of the garage sales that are popular in the USA ${ }^{24}$. "Sayonara sales", usually advertised on information boards and online forums for foreigners, often offer bargains where larger items are sold cheaply and smaller items are given away for free. In unison with a migrant's life-course in the host country, "sayonara sales" often remain a signature of student life

place at cafeterias rather than at people's homes, they nonetheless, gave me important perceptions on the dynamics of the migrants' material practices.

${ }^{20}$ Main K., Sandoval G. F. Placemaking in a Translocal Receiving Community: The Relevance of Place to Identity and Agency // Urban Studies. 2014. Vol.52, N 1. P. 71.

${ }^{21}$ Ministry of Justice (Japan), December 2016 Statistics on the Foreigners Registered in Japan. URL: http://www.e-stat.go.jp/SG1/estat/List.do?lid=000001177523 (accessed 17.11.2017).

${ }^{22}$ Golovina K. Nihon ni okeru ijūsha no maihōmu: Roshiagoken komyunichi membā no jūtaku erabi to interia wo jirei ni // Seikatsugaku Ronso-. 2016. Vol.29. P. 18.

${ }^{23}$ Mukhina V., Golovina K. Roshiajin diasupora no genjo: Zainichi roshiajin ijūsha no ichizuke ni mukete // Imin Seisaku Kenkyū. 2017. Vol. 9. P. 114; Golovina K., Mukhina V. Japanese Language Learning and Employment Opportunities for Foreign Residents: Russian-speaking Migrants in Japan // Eruditi: The CGCS Journal of Language Research and Education. 2017. Vol. 1. P.21-22.

${ }^{24}$ Herrmann G. M. Valuing Affect: The Centrality of Emotion, Memory, and Identity in Garage Sale Exchange // Anthropology of Consciousness. 2015. Vol.26, N 2. P.170-171. 
and singlehood. Contrarily, many migrants continue to make purchases at second-hand shops and flea markets even after they, speaking in social terms, move upward both geographically and socially, from smaller to bigger cities, from being students to workers or entrepreneurs, from singlehood to married life. Second-hand shops are usually run by dealers, while flea markets (those that operate daily and especially those held on certain occasions, also called bazaars), host many private people who wish to sell used items in their possession.

Russian migrants turn to second-hand shops for various reasons, with budget consideration being one of them. The results of my online survey of Russians in Japan undertaken in 2016 show that $16.5 \%$ of the respondents buy furniture and $17.7 \%$ buy household items at second-hand shops ( $\mathrm{N}=154$, multiple answers question). In both cases, second-hand shops were the fifth-most popular category of 15 and 11 choices, respectively. Similarly to many migrant populations around the world, Russian migrants in Japan are not always wealthy. The aforementioned survey showed that the category of a yearly household income of 2 to 4 million yen gained the most responses (30\%), which is below the country's 2015 average household income of 5.46 million yen (Ministry of Health, Labour and Welfare 2016 ${ }^{25}$. However, rather than discussing the budget-driven mechanisms behind migrants' choices to shop in second-hand shops - which are undoubtedly present, as shown by Petrescu and Bhatli in their research on consumer behavior in the context of flea markets ${ }^{26}$ - I would like to focus on the affective forces underlying such practices.

Daniels, whose research is particularly important for the purpose of this paper because it deals with material culture in Japan, recalls her own experience of obtaining an item at a Kyoto bazaar. She bought a toaster, sold for a token price, with a message from the owner asking the buyer to treat the item well by providing it a good home (Daniels 2009: 396) ${ }^{27}$. The second-hand shops that I focus on in this chapter are slightly further from bazaars or flea markets in terms of the experience of sociality they provide (e.g., the possibility of communication between an actual owner of an item and its successor). They, nevertheless, function as the locales of affect, where affect is an "intersubjective" force circulating "among bodies" and moving "from person to person" 28 . In the case of second-hand shops, the absence of owners allows one to enact an imaginative effort in interpreting the possible affects associated with the material discoveries of the used items and inherit a personalized version of somebody else's history. As such, in a situation of displacement, second-hand shops provide the migrants with an opportunity to transcend their displacement by means of connecting to authentic - even if not necessarily their own - pasts.

When the purchase of an item takes place through an unconventional procurement channel, such as a second-hand shop or an online buy-sell group within a migrant community, the act retains the features of DIY, or, at the very least, of co-making ${ }^{29}$. Such pur-

${ }^{25}$ Ministry of Health, Labour and Welfare (Japan), 2016 Comprehensive Survey of Living Conditions. URL: http://www.mhlw.go.jp/toukei/saikin/hw/k-tyosa/k-tyosa16/index.html (accessed 17.11.2017).

${ }^{26}$ Petrescu M., Bhatli D. Consumer Behavior in Flea Markets and Bottom of the Pyramid Marketing // Journal of Management Research. 2013. Vol. 13, N 1. P.60-61.

27 Daniels I. The 'Social Death' of Unused Gifts: Surplus and Value in Contemporary Japan // Journal of Material Culture, 2009. Vol. 14, N 3. P. 396.

${ }^{28}$ Herrmann G. M. Valuing Affect... P. 171.

29 Golovina K. Material'naya kul'tura i bricolazh: kak russkoyazychnye migranty sozdayut i priobretayut veshchi // Antropologicheskij Forum. 2017. Vol.34. P. 180. 
chases require extra efforts, engagement, and time on the part of the buyer and often on the part of the seller. Extensive communication and physical movement outside one's route of convenience are sometimes involved. Further, the buyer has to partake in the transaction on an affective level, where the purchase is not just an exchange of money and goods, but of emotional tensions encapsulated in the objects and experienced by the transactions' participants. To have the object fit their environment, the buyer may have to turn to actual DIY by modifying (e.g., repainting or remodeling) the purchased item. This presents a stark contrast with conventional modern-day shopping, which trades "fungible, antiseptic commodities entombed in layers of plastic from contemporary stores"30.

During the initial years of their life in Japan, many of my respondents turned to second-hand shops and flea markets to find Japanese decorative objects such as clay figurines, wall-hung swords, and traditional hina dolls in large glass boxes to satisfy their desire for exoticism. One respondent - a fully employed Russian in her early thirties at the time of the interview - mentioned the famous Osu Shopping District in Nagoya that hosts multiple second-hand shops. Another respondent, Elsa ${ }^{31}$, reported that she frequents similar locations to buy Japanese souvenirs before visiting her family and friends in Russia. She said, "Buying a new Japanese-style teapot like this at a department store would cost me a fortune, but here I can find something beautiful, with an antique flavor, and for a fraction of a price. It is always nicely packed, sometimes in wooden boxes. And it has never been used!" Although such an object might have never been used to serve its initial purpose, it has been used in a way of being stored at someone's home before being sold or given away to a second-hand shop. In her account of Japanese gift-giving from the point of view of surplus and value, Daniels talks about the "social death" of unused gifts, providing a description of how the items initially targeted at one's relative or benefactor end up at flea markets ${ }^{32}$. Following Daniels' interpretation of the trajectory that some gifts in Japan follow - from the point of being chosen by someone to the point of appearing at a second-hand shop - it would be difficult to imagine that such an item was purchased again by a Japanese person as a gift for someone else. In other words, if a Japanese person does buy such an item at a second-hand shop, it would be most likely for personal use. Yet, the item acquires a chance to participate in an affective practice of gift-giving once more thanks to being purchased by someone who stands outside Japan's socio-cultural logic (i.e., a migrant). The item's "cultural biography" 33 thus continues with a transnational relocation.

My findings reveal that the purchasing of items that evoke the sentiment of exoticism tends to become less common as the migrant settles in the country and spends more years there. As a result, migrants start turning to other types of things in the second-hand shops. Many of the respondents voiced their dissatisfaction with the range of items and especially clothes sold at Japan's conventional stores. Clothing sizes were one such concern. Kristina, a woman in her late twenties, mentioned that because second-hand shops hosted items that the Japanese people "did not want [since the items were at a second-hand shop rath-

${ }^{30}$ Herrmann G. M. Valuing Affect... P. 171.

31 The names of the informants and organizations directly discussed in this paper have been altered to secure the privacy of those studied.

32 Daniels I. The "Social Death" of Unused Gifts: Surplus and Value in Contemporary Japan. P. 399.

${ }^{33}$ Kopytoff I. The Cultural Biography of Things: Commoditization as Process // The Social Life of Things: Commodities in Cultural Perspective: The Social Life of Things / ed. by A. Appadurai. Cambridge, 1986. P. 64 . 
er than in someone's possession - K.G.], it is possible for us [foreigners] to find there what we want, both size- and fashion-wise. There are many items by overseas brands". As such, she was looking for clothes that she perceived as fitting her and matching her taste, suggesting that non-Japanese brands (but also non-Russian brands, since Russia is not active in worldwide retail fashion) are better at achieving this fit and match. Through such sentiments, she was enhancing her identity as a "foreigner" in Japan. Interestingly, this respondent's mother, who upon visiting Japan reportedly noticed her daughter's second-hand shopping, is said to have warned her daughter to not buy and wear second-hand jewelry, especially pearls, saying, "Too much of somebody else's energy. You could attract bad luck". This is a direct example of the perception of the objects as the containers of histories and energies. Another respondent, a Russian with Uighur roots, said she started frequenting second-hand shops after she found a "tinkling" blouse with beads (монисть) that she felt resembled her deceased grandmother's attire. She could actually never even speak with her grandmother because she did not know her native language. Nevertheless, the respondent had her image strongly imprinted in her heart. These affective encounters with the items make one feel more rooted in their selves, regardless of what kind of selves people choose for themselves in the fluidity of migrant everydayness. Following Latour's logic, the objects under discussion here serve as mediators rather than means because the resulting identities born out of the encounters migrants have with these objects "exceed" the initial characteristics of the individual or object in question ${ }^{34}$.

In an account of migrant material practices conceptualized through the notion of bricolage, I have shown how Russian migrants in Japan often visit second-hand shops without a particular purpose, in search of something that would resonate with their mode of being on a particular day ${ }^{35}$. This lack of purpose, however, does not mean that what they do purchase is "random". On the contrary, it is predetermined by an organizing socio-cultural logic that serves as an indication of their transforming identities. I have observed a trend among Russians in Japan to purchase items resembling European pieces from older times $^{36}$. They include art-nouveau ${ }^{37}$ lamps that are unusual in Japan, porcelain statuettes, and tall flowered coffeepots, which my informants see as being of a "European" origin. Many informants spoke about these items as being in line with their unique visions of themselves. Valeria, who came to Japan nearly twenty years ago, and is married to a Japanese man, has filled her Japanese home with exquisite porcelain dinnerware, which she mainly procured in second-hand shops. When the items come to inhabit the informants' homes, they function to produce distinction ${ }^{38}$ and represent a certain part of their own-

34 Latour B. On Interobjectivity... P. 237-240.

35 Golovina K. Material'naya kul'tura... P. 193-196.

${ }^{36}$ In the account on the representation of concepts of "Europe" and "the West" in the online forums of the UK-based Russian-speaking migrants, Morgunova argues that "the participants reproduce the discourse of supremacy that was typical for late nineteenth century imperial Europe". Morgunova O. Europeans, not Westerners: How the Dilemma "Russia vs. the West" is Represented in Russian Language Open Access Migrants' Forums (United Kingdom) // Ab Imperio. 2006. Vol. 3. P. 409-410. Morgunova concludes that “[m] igrants discuss the role and place of Russian culture within the European tradition, and construct the culture of the "Other" as non-European" // Ibid. P. 402.

${ }^{37}$ For detailed discussion of the case where one of the informants particularly favors art-nouveau style, see: Golovina K. Material'naya kul'tura... P. 193-196.

38 Bourdieu P. Distinction: A Social Critique of the Judgement of Taste. Cambridge, 1984. P. 260. 
ers' identity. Buchatskaya ${ }^{39}$ has shown, for example, how material objects in the homes of German gardeners serve the purpose of telling a story of their "professional identity". For Valeria, rather than telling the story of her occupation, the objects in her home narrate her coming into her present being, where these objects serve to connect her past through the present to the future. These practices, while perceived by her as distinctively individualistic, are simultaneously a form of "we-ness", where Valeria, similarly to many other Russians in Japan, positions herself as an inheritor of European traditions and taste. As Weiner has described in her anthropological account of the principles surrounding the functions of human possessions, "individuals and groups work with exacting care to recreate the past for the present so that what they do in the present affects the future" 40 . Possessions are also at play when people "attempt to transcend their own genealogies" 41 . Further, since home can be seen as the only place where one remains within the boundaries of one's personality ${ }^{42}$ because "personality consists of a specific social consciousness of material scale, apportioned by one's property, the things in one's room [...]"43, the objects telling the story of one's identity are infused with an ontological quality.

Petrescu and Bhatli have introduced the narrative of one of the attendees of the flea market under their investigation where the person says that these locations "remind [her] of home", suggesting that the respondent is a migrant. She further explains that she enjoys flea markets because "ethnic food" could be found there ${ }^{44}$. Petrescu and Bhatli argue that the markets' attendees find "cultural diversity" important ${ }^{45}$. These findings are comparable to what the respondents in my study mentioned as driving them to the second-hand shops in Japan: foreignness, ancestral roots, and Europeanness. Even their initial exoticist sentiments could be interpreted as part of this continuum. They are looking for alternatives to the mainstream experiences of modern-day Japan, for cultural diversity, if not of human contact, then of the affective contact with the one-of-a-kind objects on display in second-hand shops. These encounters speak to their sense of self, which transforms along the course of their migrant life.

\section{Discussion 2: Staged Performances and Handmade Costumes}

This chapter discusses the material practices - the making and using stage costumes - at a theatrical play as part of a migrant festival organized by a private Russian school, Mir, in Tokyo. A few reflexive remarks have to be made before I proceed to the discussion. Had I not been Russian myself, I may not necessarily have read into the multiple connotations of the performance and "recognized" the familiar features in the handmade costumes the performers were wearing. As Pechurina, a Russian migrant herself, who conducted a study of "sensory" migrant homes in the community of Russians in the UK puts it, "[...] familiarity with both Soviet and Russian cultural contexts aided the

${ }^{39}$ Buchatskaya Y. Interier i veshchi v kontekste professii. Nablyudeniya v domah gorodskih ovoshchevodov Bamberga // Antropologicheskij Forum, 2016, vol. 30. P. 186.

40 Weiner A. B. Inalienable Possessions: The Paradox of Keeping-While-Giving. Berkeley and Los Angeles, 1992. P.7.

${ }^{41}$ Ibid. P. 132.

42 Rives R. Modernist Impersonalities: Affect, Authority, and the Subject. New York, 2012. P. 41-46.

43 Ibid. P. 45.

${ }_{44}$ Petrescu M., Bhatli D. Consumer Behavior... P. 59.

45 Ibid. 
understanding and interpretation of meanings and implications suggested by the respondents, such as specific stereotypes or common-sense topics" ${ }^{36}$. By extension, it means that a similarly positioned researcher can read into the meanings of the observed actions and manipulated objects.

Mir is located in one of the busiest areas in central Tokyo and occupies a one-room space in an old six-story building. Opened recently, this school is notable in many ways because it combines daycare, elementary, and middle school in one place. It also has a number of "classrooms", for subjects from Slavic culture, chess, and art to flower arrangement, English, and Chinese. The Russian school Mir also has a theatre studio, where its young participants can perform for various cultural events organized by the school, some of which fall on Russian national holidays or other holidays carrying cultural or political meanings. For instance, on April $1^{\text {st }}$ 2017, the school arranged an event called "The Anniversary of Korney Chukovsky", one of the most famous Russian and Soviet children's poets. Events of this kind are usually organized in the rented community halls in the proximity of Mir and are free for children enrolled in the school. "The Anniversary of Korney Chukovsky" consisted of two parts: the staged performance of the poet's perhaps most famous long poem, "Buzzy-Wuzzy, Busy Fly" (1932), and a poetry competition, where the children recited poems they had learnt by heart. The performers wore handmade costumes and were of all ages (from approximately 2 years old to young adolescents). The majority of the children were born to Russian mothers and Japanese fathers. There were also children where both parents were Russian, but were raising their children in Japan because of their work in that country. Some others were born to a Russian father and a Japanese mother.

While the current generation of Russian female migrants in Japan are usually younger than the "last Soviet generation" described by Yurchak ${ }^{47}$, the majority of these women still attended kindergartens or even elementary school during the last ten years of the Soviet Union. Perhaps because childhood memories are so strong and defining, they remain intact despite the multiple layers of experiences this population has undergone both in post-Soviet Russia and in Japan. Mir is a place where the childhood memories of both its principal, an energetic woman in her 40s, and the Russian parents who bring their children there are enacted. For instance, the children's readings of the poems learnt by heart immediately evoked memories of the late Soviet celebrations involving children. Kelly and Sirotinina, who discuss Soviet festivals as seen by children from the 1950s to the 1990s, bring an example of poem recitals as one of the constituents of the kindergarten celebrations enjoyed by children for their "holiday feeling" ${ }^{48}$. Mir is affectively charged as a "Russo-Soviet" location in Tokyo, where such feelings and memories are reproduced.

Here I return to the scene of the "Buzzy-Wuzzy, Busy Fly" performance. Combining stage settings, costumes, performance, songs, dancing, and lighting, the play emerged as a multimodal production that unfolded on a nearly floor-level stage of a communal hall. The floor was covered with Japanese tatami, emanating a characteristic smell, and the

46 Pechurina A. Material Cultures, Migrations... P.77.

47 Yurchak A. Everything Was Forever, Until It Was No More: The Last Soviet Generation. Princeton and Oxford, 2005. P.31-32.

${ }^{48}$ Kelly C., Sirotinina S. "I Didn’t Understand, But It Was Funny": Late Soviet Festivals and their Impact on Children // Russian Cultural Anthropology after the Collapse of Communism / eds A. Baiburin, C. Kelly, N. Vakhtin. London; New York, 2012. P. 117. 
viewers were required to leave their shoes upon entering. Since there were no chairs, in accordance with the conventions of a tatami room, the viewers sat on the floor, which created a sense of intimacy between the viewers and performers. The fragrance of the Japanese tatami mixed with the aroma of the perfumes worn by the Russian men and women, which is uncharacteristic for a Japanese-only space, produced a new kind of a sensory experience.

As the storyline of the poem demands, the performers wore the costumes of various insects, from bees to butterflies. The heroine, a lady fly, changed her costume several times throughout the play. The costume of the protagonist, a brave mosquito, emerged as that of a bright knight. It contrasted with the gloomy attire of the antagonist, a spider. The play opens and closes with a feast, and one of the central elements is a samovar, a Russian traditional device to boil water. A samovar crafted from yellow paper was carried by a girl wearing a traditional Russian dress, sarafan, in red. The school's principal, who acted as the play's coordinator, was also wearing a similar sarafan. The girl carrying the samovar could have been dressed as an insect, seeing as the play depicts a story from the life of insects, yet her Russian identity was intensified through the use of the sarafan costume. These perceived markers of Russianness - the water-boiling device and the dress - could be interpreted as what Pechurina calls "diasporic objects" 49 . The samovar and sarafan fall into a category of traditionally Russian items that call into being an ethnic referral in the course of being procured or made, displayed, and used by the members of Russian diaspora worldwide.

The handmade costumes of the performers combined a range of techniques and materials. While the majority looked like remodeled clothes, there were some minor items like shoes and tights that were matching ready-made items purchased at stores. The clothes, especially those of the main heroine, were exquisite for an amateur children's production. This performer first appeared on stage wearing a white dress with the elements of a robe, its broad belt made of shiny golden material, resembling a fly's belly. A square emerald cap crowned her head, with two wings on top of it. Later, at a mise-en-scene of the wedding between the mosquito and the fly, the heroine wore a grandiose emerald dress in the style of $18^{\text {th }}$ century European attire.

Tsuda interprets similar practices involving home-made costumes by Nikkeijin Brazilians in Japan as "culturally decontextualized" and "amateurish" to a point of being "a pale imitation" of the real Brazilian festivities, stressing that they carry ethno-national meaning only in $\operatorname{Japan}^{50}$. In his research on a Russian-speaking community in the UK, Byford's version of the ethno-national element as seen through the migrants' festivals is that their participants engage in "performing the big community", where the "big community" is perceived as some indefinable group of people who possess a shared identity of being Russian outside Russia ${ }^{51}$. As such, the "performativity" of these festivals renders their "amateurishness" unimportant because they serve a purpose of enabling participants to imagine themselves as part of a bigger "we". The festivals are not required to deliver wholeness, but

49 Pechurina A. Material Cultures, Migrations... P. 34-38.

${ }^{50}$ King R., Christou A. Diaspora, Migration and Transnationalism: Insights from the Study of Second-generation "Returnees" // Diaspora and Transnationalism Concepts, Theories and Methods / eds R. Bauböck, T. Faist. Amsterdam, 2010. P. 174.

51 Byford A. Razygryvaya "soobshchestvo": russkoyazychnye migranty sovremennoy Britanii // Novoe Literaturnoe Obozrenie. 2014. Vol. 127. P.377-395. 
only hints and associations. The symbolic meanings of enacting community by providing associations through material objects may be of particular importance for the coordinator of the project, the school's principal, who has to manipulate multiple forces (including attracting funding and new students) to make her school a success. These meanings are affectively supported from below: by those who assist in preparing the festival and those who perform, and I argue that handmade costumes play a particular role in this process.

To deliver a "product", a handmade costume for her child to recite, sing, and dance in on the stage of a community hall, a Russian mother has to engage in an act of creativity. Relying on her memory (but also on the relevant Russo-Soviet imaginaries available on the Internet), she labors affectively. She invests time and effort into thinking about the appropriate design, evaluating materials available at her home, purchasing additional materials (unsurprisingly, often at second-hand shops), and actually remodeling, sewing and making her child try the attire on in an act of production. Fuchs et al. have suggested the existence of a positive handmade effect in consumer behavior. A handmade product possesses "positive contagion" and the maker's emotion of love ("artisanal love") is contained in it $^{52}$. While this chapter's findings are not set in a buyer-seller setting, the positive handmade effect still stands. The affectively-suffused costumes, passed on from a mother to her child in my study, participate in a process of cultural reproduction. This cultural reproduction has to do with conveying to her Japan-born child the Russo-Soviet imaginaries through associations and hints (due to one's inability to provide "wholeness" in the context of physical displacement). Because such handmade costumes are not just made and given, but worn and displayed at a theatrical performance - another powerful locale of affect - in front of a perceivably like-minded audience, these costumes mediate authenticity and provide the social effect of enacting the sense of belonging to "we", the Russians with the Soviet past. After the performance, the costumes stay with the owner and are sometimes used in other productions. Although an informant mentioned the possibility of passing down the costume to another child, which would prompt situations of giving or exchange, I have not encountered such cases in this portion of my fieldwork.

\section{Discussion 3: Craft Practices in Online Spaces}

This chapter focuses on the craftwork-related practices by Russians in Japan taking place in online spaces. The "Russian-speaking community in Japan" on Facebook is the largest and fastest growing online group of Russian and Russian-speaking (from post-Soviet states) migrants in Japan. It was initially launched as a support group for Japan's Russian-speaking population in 2011, following the Great East Japan Earthquake ${ }^{53}$. It resem-

${ }^{52}$ Fuchs C., Schreier, M. Van Osselaer S. M. J. The Handmade Effect: What's Love Got to Do with It? // Journal of Marketing. 2015. Vol.79, N 2. P. 100-101. - Fuchs, Schreier, van Osselaer's discussion of the handmade effect in consumer behavior does not offer a critical perspective on the idea of "who" stands behind the production and is thus detached from the associations with sweatshops and hard labor behind many handmade items. In doing so, the authors highlight the worldview of a regular Western consumer who perceives handmade products as uniquely tailored in boutique-style workshops. This paper also refers to the "one-of-a-kind", positively affected nature of crafted objects as this is in line with how the objects in my findings are indeed made. However, it is important to keep in mind that handmadeness can be, and in fact is in many cases, charged with the negative affects of exhausting work and cheap labor.

53 The details of how this online group came to be were recorded during an interview with an informant as part of the 2016 joint project with Varvara Mukhina. 
bles the spirit of unity shown by Russians in Japan after both the 1923 Great Kanto and 1995 Great Hanshin Earthquakes ${ }^{54}$. Many similar online communities have been formed in the past six years, attracting various groups of Russian speakers in Japan. Nevertheless, the "Russian-speaking community in Japan" group remains the largest with 11,126 members, as of July 2017. Once people are acquainted with each other to a certain extent, smaller, more targeted groups started to appear, such as "Buy-Sell" or "Give for Free" groups, where Russians sell, buy, and give furniture, interior items, clothes, children's products, and books in Russian, English, and Japanese. Some people established small-scale businesses where they bulk-order items such as beauty products or books in Russia and sell them to members of the community in Japan, although data in regard to the profitability of these initiatives is not currently available. The fact that "objects", very often from or representing Russia in some way, surface so vividly in these online spaces can be considered in conjunction with Newell's interpretation of the meaning of digitized objects for indigenous communities. Newell argues that "digitization has increasingly been seen as a politically and culturally valid means of keeping objects as active participants within the community" ${ }^{\prime \prime}$. While her discussion focuses on the museum industry and the practice of digitalizing museum collections, it highlights a perspective equally important for my research: online spaces, where digital versions of various objects circulate, function as "storage" for affective memory that makes visible the world of objects from the migrant past and gives these objects a chance to serve certain functions within the migrant community.

I have described elsewhere how interior products initially brought from Russia or merely resembling Russo-Soviet designs, such as chandeliers or wallpaper, find customers in these online Russian-speaking groups ${ }^{56}$. I argued that many such purchases are carried out impulsively, when familiar items appear as one scrolls the Internet pages, triggering emotions such as nostalgia, sentimentality, and commonality. These processes can be interpreted as being affectively-determined, where collective memory and shared tastes are called into being. In this paper, I focus on one case involving a handmade item. The online group "Our People" is one of the locations where administrators often organize money-gathering activities and auctions to help Japan-based Russians in trouble. Very often the troubles involve Russian women in international marriages whose partners are non-Japanes nationals, and who have not yet obtained permanent residency in Japan. Should such a couple divorce, these women lose their residential status and struggle to secure residency. The process is often difficult, despite them having children. Because applicants are not allowed to work when undergoing a process of status change, these women find themselves in a situation where they cannot provide for their children. The most recent donation and auction activities undertaken in "Our People" targeted two such women.

As far as my cyberethnographic observations permit me to conclude, these auctions (unlike direct donations similarly facilitated through "Our People") are not particularly active, perhaps generating only a few thousand yen per calling for the person in trouble. However, handmade products are often posted in these fundraisers. The latest examples

${ }^{54}$ Podalko P.: 1) Hakkei Roshiajin to Nippon. Yokohama, 2010. P. 27-49; 2) Russians in Japan: A Historical Perspective, delivered at Aoyama Gakuin University, Tokyo, on April 23, 2016.

${ }_{55}$ Newell J. Old Objects, New Media: Historical Collections, Digitization and Affect // Journal of Material Culture. 2012. Vol.17, N 3. P. 300.

${ }^{56}$ Golovina K. Material'naya kul'tura... P. 200-202. 
included handmade candles with dried flowers inside, jewelry, and textile decorations. Handmade products are also purchased more willingly. When an auction to support Ariana from central Japan was launched in spring, a group member from the southwest of Japan posted a photograph of three handmade brooches, hydrangeas (the flowers of the season) made from Japanese traditional wrinkled crepe (chirimen) in green, blue, and white. The auction works in a way that the user suggests a price higher than the starting price offered by the maker in a thread below the photo of the offering. The process continues with new offers appearing in the thread until interest diminishes and the group administrator announces the "winner". The auction then stops being transparent and is built on goodwill. The purchaser is supposed to send the money to the account of the person in need and is not required to present any confirmation to the administrator of the group. Meanwhile, the maker sends the product directly to the purchaser. Because the monetary recipients in these transactions are usually overwhelmed by the immigration office procedures and the precariousness of their situations, they do not give feedback regarding the receipt of the money.

Out of anthropological interest, I wanted to acquire one of these brooches. I participated in the auction and became the winner, after which I took part in the financial transaction. The brooch I received was a piece of fine work. When I asked the maker about her work, she replied, "I do not make items for sale as I do not see any meaning in it. Being a creative person, I usually make some for friends." Her Facebook page indeed hosts photographs of many beautiful handmade items, from bags to clothes and quilts. About the auction, she replied that it was her first time participating. She decided to do so because she "felt positive about Ariana", although the two have never met.

The trajectory undergone by affect in this situation is notable: the group's administrators were affected by Ariana's situation (through the woman's posts in the group and personal contact) and moved to affect the other members of the group by first sharing her story with the audience and then by initiating the auction. The brooch's maker was affected by Ariana's story, which was shared by the administrators (with several comments by Ariana herself in the thread), and chose to contribute a newly-crafted item, which she had made with friends in mind to the auction, thus, sharing her affect to Ariana, if not as a friend but as a person she "feels positive about", infused in the object. While the object, perhaps the most concentrated container of the emotions described, does not end up with Ariana, it affects the buyer in a way that he or she has made a decision to make a monetary contribution to Ariana's cause. While the buyer might have been affected by Ariana's situation (similarly to the maker), it is the product's nature that functions as triggering the transaction. Its handmadeness positions it as infused with humane emotions, which are enhanced by the cause of the transaction: helping a struggling fellow-compatriot in a foreign land. Along the way, new connections (between sellers and buyers) are built. Finally, the affect reaches Ariana in the form of a monetary contribution, the only possible contribution that can effectively help her in her situation. As trauma is central to identity construction $^{57}$, it may have been the trigger to launch the flow of affective forces in this collective imagining of displaced selves ${ }^{58}$.

57 Athanasiou A., Hantzaroula P., Yannakopoulos K. Towards a New... P. 10.

58 There are situations when online migrant groups become spaces where negative affects are generated, some corresponding with the ways larger online spaces give forth to phenomena such as shaming. In the case discussed in this chapter and other similar cases gathered as part of this research, I often observed how 
Miller has suggested that Facebook, where the described transactions took place, possesses "perceived and actual ability to reconstruct relationships, especially within families and with absent friends, that had been gradually fading away due to the attrition of other aspects of modern life, such as increasing mobility" ${ }^{59}$. He further argues that Facebook helps one "return to the kind of involvement in social networks [in an anthropological sense $-K . G$.] that we believe we have lost" ${ }^{60}$. The case above shows how Facebook also enables affect to be shared and sustained among people and material objects in the most immediate and sensorial form, despite communications occurring in a so-called "virtual" space.

When I started my fieldwork in 2008, online social networks were almost never mentioned by my informants. Many complained of not being able to find Russian friends, lacking a chance to converse in Russian, and feeling lonely and isolated. At the time, people had just started using Skype to call home, largely because it was at around that time that their Russian relatives gained the opportunity to access technologies in a freer manner. Many still used old-fashioned and expensive telephone cards to connect to their loved ones in Russia. The informants' feelings of loneliness were real, and the fast growth and activeness of the online groups described above confirm that people had indeed been longing for sociality. The charity auction represents how the possible forms of sociality exceed merely the opportunity to converse in Russian, instead taking complex multilayered forms of affective interactions. They enable people to form and sustain relationships and objects to travel spatially as the carriers of people's affective dispositions that serve the greater purpose of enacting a community.

\section{Concluding Remarks}

This paper combines discussions focusing on three cases involving material practices by Russians in Japan: second-hand shopping, costume-making for theatrical performances, and online transactions involving handmade items. Extended descriptions of each of the occurrences were added in order to provide a larger socio-cultural context and, following the objectives of an "evocative ethnography", to relay to readers the affective underpinnings of the recorded material practices. The three cases, selected from many similar ones gathered in the course of my fieldwork, are illustrative in terms of their ability to show how the objects involved in various material practices by the migrants help capture the otherwise undetectable affective forces that circulate between people. The objects (a used outfit with ethnic motives from a second-hand shop, an elaborate DIY costume for a stage performance, and a handmade flower brooch traded at a philanthropic auction) act as containers and mediums of affect. Their physicality, the stiches and staples craftwork requires, function to not only sew together pieces of cloth and ornaments, but to enfold the unseen motives behind the actions migrants undertake individually and as a

the group's administrators diligently performed the role of conciliators when harsh comments doubting the legitimacy of the plight of the charity-seeking members were posted. Since the administrators took a strong stand to protect the women, they were organizing the auctions for, they managed to achieve a favorable resolution to these situations in the majority of cases. When the administrators themselves were blamed for trying to achieve personal publicity through auctions and similar events, they actively responded by providing careful accounts of the situations and defending themselves.

${ }^{59}$ Miller D. Tales from Facebook. Cambridge, 2011. P. 217.

${ }^{60}$ Ibid. 
community. Making such objects the focus of attention reveals some of the nature of the identity dilemmas and longing for community belonging and relationships experienced by many migrants, both in the present and in the realm of the pre-migratory past, where it relates to one's memories of ancestral roots. At times, these affective longings are directed at the future, as when one's participation in an auction surrounding trauma functions as an attempt to ease one's own pain, to establish a vision of a migrant experience free of uncertainty. Flowing through bodies spatially and temporally, affect "settles" when nested in material embodiments that further serve to create a transplanted social reality for migrants in a foreign land.

\section{Acknowledgements}

I thank Japan Society of Lifology for their funding of the online survey I undertook in 2016 about the homes and objects of the Russian-speaking migrants in Japan. An earlier draft of this paper was presented as part of the "Sensory Ethnographies in Spaces of Co-Production: The Quest for Alternative Immersive Experiences" panel at European Association for Japanese Studies 2017 in Lisbon, Portugal. I thank the organizers of the Anthropology and Sociology section, Andrea de Antoni and Emma Cook of Japan Anthropology Workshop, for setting "affect" as an overarching topic of the section and thus enabling the presenters to explore their findings from this new perspective. My gratitude also goes to Beata Switek, the discussant at our panel, for her valuable insights. I thank Ksenia Kurochkina and Varvara Mukhina for their comments on the earlier draft of this paper. Finally, I express my gratitude to the two anonymous reviewers for their constructive feedback.

\section{References}

Athanasiou A., Hantzaroula P., Yannakopoulos K. Towards a New Epistemology: The "Affective Turn". Historein, 2008, vol. 8, pp. 5-16.

Bourdieu P. Distinction: A Social Critique of the Judgement of Taste. Cambridge, Harvard University Press, 1984,613 p.

Buchatskaya Y. Interier i veshchi v kontekste professii. Nablyudeniya v domah gorodskih ovoshchevodov Bamberga. Antropologicheskij Forum, 2016, vol. 30, pp. 175-214. (In Russian)

Búriková Z. The Embarrassment of Co-Presence: AU Pairs and their Rooms. Home Cultures: The Journal of Architecture, Design and Domestic Space, 2006, vol. 3, no. 2, pp. 99-122.

Burrell K. Managing, Learning and Sending: The Material Lives and Journeys of Polish Women in Britain. Journal of Material Culture, 2008, vol. 13, no. 1, pp. 63-83.

Byford A. Razygryvaya "soobshchestvo": russkoyazychnye migranty sovremennoy Britanii. Novoe Literaturnoe Obozrenie, 2014, vol. 127, pp. 377-395. (In Russian)

Caldwell M. L. Dacha Idylls: Living Organically in Russia's Countryside. Berkeley; Los Angeles, University of California Press, 2010, 200 p.

Daniels I. The 'Social Death' of Unused Gifts: Surplus and Value in Contemporary Japan. Journal of Material Culture, 2009, vol. 14, no. 3, pp. 385-408.

Doi K. Onto Emerging Ground: Anticlimactic Movement on the Camino de Santiago de Compostela. Turizam: međunarodni znanstveno-stručni časopis, 2011, vol. 59, no. 3, pp. 271-285.

Fuchs C., Schreier M., Van Osselaer S. M. J. The Handmade Effect: What's Love Got to Do with It? Journal of Marketing, 2015, vol. 79, no. 2, pp. 98-110.

Golovina K. Nihon ni okeru ijūsha no maihōmu: Roshiagoken komyunichi membāno jūtaku erabi to interia wo jirei ni. Seikatsugaku Ronso-[Journal of Lifology], 2016, vol. 29, pp. 15-29. (In Japanese)

Golovina K. Nihon ni kurasu roshiajin josei no bunkajinruigaku: Iju, kokusai kekkon, jinseizukuri. Tokyo, Akashi Shoten, 2017, 472 p. (In Japanese) 
Golovina K. Material'naya kul'tura i bricolazh: kak russkoyazychnye migranty sozdayut i priobretayut veshchi. Antropologicheskij Forum, 2017, vol. 34, pp. 179-210. (In Russian)

Golovina K., Mukhina V. Japanese Language Learning and Employment Opportunities for Foreign Residents: Russian-speaking Migrants in Japan. Eruditi: The CGCS Journal of Language Research and Education, 2017, vol. 1, pp. 17-35.

Herrmann G. M. Valuing Affect: The Centrality of Emotion, Memory, and Identity in Garage Sale Exchange. Anthropology of Consciousness, 2015, vol. 26, no. 2, pp. 170-181.

Kelly C., Sirotinina S. 'I Didn't Understand, But It Was Funny': Late Soviet Festivals and their Impact on Children. Russian Cultural Anthropology after the Collapse of Communism. Eds A. Baiburin, C. Kelly, and N. Vakhtin, London, New York, Routledge, 2012, pp. 103-129.

King R., Christou A. Diaspora, Migration and Transnationalism: Insights from the Study of Second-generation 'Returnees'. Diaspora and Transnationalism Concepts, Theories and Methods. Eds R. Bauböck, T. Faist. Amsterdam, Amsterdam University Press, 2010, pp. 167-184.

Kopytoff I. The Cultural Biography of Things: Commoditization as Process. The Social Life of Things Commodities in Cultural Perspective. Ed. by A. Appadurai. Cambridge, Cambridge University Press, 1986, pp. 64-92.

Main K., Sandoval G.F. Placemaking in a Translocal Receiving Community: The Relevance of Place to Identity and Agency. Urban Studies, 2014, vol. 52, no. 1, pp. 71-86.

Latour B. On Interobjectivity. Mind, Culture, and Activity, 1996, vol. 3, no. 4, pp. 228-245.

Martin E. The Potentiality of Ethnography and the Limits of Affect Theory. Current Anthropology, 2013, vol. 54, no. S7, pp. 5-16.

Miller D. Tales from Facebook. Cambridge, Polity, 2011, 220 p.

Morgunova O. Europeans, not Westerners: How the Dilemma "Russia vs. the West" is Represented in Russian Language Open Access Migrants’ Forums (United Kingdom). Ab Imperio, 2006, vol. 3, pp. 389410.

Mukhina V., Golovina K. Roshiajin diasupora no genjo- Zainichi roshiajin ijusha no ichizuke ni mukete. Imin Seisaku Kenkyü, 2017, vol. 9, pp. 105-122. (In Japanese)

Newell J. Old Objects, New Media: Historical Collections, Digitization and Affect. Journal of Material Culture, 2012, vol. 17, no. 3, pp. 287-306.

Pechurina A. Material Cultures, Migrations, and Identities: What the Eye Cannot See. Basingstoke and New York, Palgrave Macmillan, 2015, $171 \mathrm{p}$.

Petrescu M., Bhatli D. Consumer Behavior in Flea Markets and Bottom of the Pyramid Marketing. Journal of Management Research, 2013, vol. 13, no. 1, pp. 55-63.

Podalko P. Hakkei Roshiajin to Nippon. Yokohama: Seibunsha, 2010, 222 p. (In Japanese)

Rives R. Modernist Impersonalities: Affect, Authority, and the Subject. New York, Palgrave Macmillan, 2012, 219 p.

Shakuto S. Ageing with Bad-Boy Charm: An Affective Analysis of Japanese Retirement Migration in Malaysia. Japanese Review of Cultural Anthropology, 2017, vol. 18, 1, pp. 159-172.

Skoggard I., Waterston A. Introduction: Toward an Anthropology of Affect and Evocative Ethnography. Anthropology of Consciousness, 2015, vol. 26, no. 2, pp. 109-120.

Tsuda T. From Ethnic Affinity to Alienation in the Global Ecumene: The Encounter Between the Japanese and Japanese-Brazilian Return Migrants. Diaspora, 2001, vol. 10, no. 1, pp. 53-91.

Weiner A.B. Inalienable Possessions: The Paradox of Keeping-While-Giving. Berkeley and Los Angeles, University of California Press, 1992, 232 p.

White D. Affect: An Introduction. Cultural Anthropology, 2017a, vol. 32, no. 2, pp. 175-180.

White D. Notes Toward an Affective Anthropology of International Relations. The Hosei Journal of Global and Interdisciplinary Studies, 2017b, pp. 125-139.

Yurchak A. Everything Was Forever, Until It Was No More: The Last Soviet Generation. Princeton; Oxford, Princeton University Press, 2005, 352 p.

Received: 23.11 .2017

Accepted: 30.03 .2018 